\title{
Translator's Gender and Culture Ideology: A Case Study of the Translation of Eka Kurniawan's Cantik Itu Luka Into Beauty is A Wound
}

\author{
Dwi Pratiwi S. Husba ${ }^{1}$, Abdul Hakim Yassi ${ }^{2}$, Noer Jihad Saleh ${ }^{3}$ \\ \{dwihusba@gmail.com ${ }^{1}$, hakimyassi@yahoo.com ${ }^{2}$, noerjihadsaleh239@gmail.com ${ }^{3}$ \} \\ ${ }^{123}$ Universitas Hasanuddin, Makassar, Sulawesi Selatan, Indonesia
}

\begin{abstract}
There are some Indonesian works of literature, especially novels, have been translated into some languages in the world. One of them is Cantik Itu Luka written by Eka Kurniawan and has been translated into more than 30 languages. This novel has been translated into English by Annie Tucker. Annie Tucker is a translator and writer specializing in Indonesian literature, arts, and culture. She is an American who loves Indonesian culture and art. The story of this novel combines history, satire, tragedy, legend, humor, and romance. This novel narrates about a beautiful Indo prostitute, Dewi Ayu, and her four daughters that are assailed by incest, murder, bestiality, rape, insanity, monstrosity, and vengeful undead. The story of this novel weaves its way through Indonesian's history that describes the society's life of Dutch colonialism to the modern age of Independence that automatically presents the cultural sides of the society at that time. Besides, gender issues as portrayed in this novel become such an interesting thing to discuss. Since the writer of this novel is Indonesian male and the translator is American female, this study focused on translators' ideology in translating two significant items carried out in this novel; cultural and gender sides. How gender and cultural ideologies of the ST into TT are interpreted and transformed by the translator. This study was a descriptive qualitative. After analyzing, this study shows that foreignization ideology of the translator is dominant in translating cultural-related terms. The translator keeps maintaining all terms, which really characterize Indonesian, while in gender ideology perspective of the translator shows that translator's successfulness in understanding the writer's ideas although some sample data cause distortion because the translator loses some dramatic moments in the story.
\end{abstract}

Keywords - Beauty is a wound, cantik itu luka, culture, gender, ideology, translation

\section{Introduction}

Many products of translation are considered successfully impress the reader when the products, in this case, the translation of the target text can be understood well and it seems as not as a result of the translation. The translator itself genuinely plays a significant role in this 
part. However, being a translator is not always expected to translate literally, yet deliver the meaning. As stated by Hamerlain (2005) that it is all the right of the translator to maintain the meaning of source text (ST) into target text (TT) since it must be based on translators' belief and point of view what the translation of source text into the target text be like [1]. Each translator has the standard to produce a good product of translation and does not consistently have the same point of view among the translator. Again and again, it must be based on the translator's ideology. The most crucial thing between translators and their products is how the readers can understand the meaning.

Free translation and literal applied to create a good translation for the target reader has become something unavoidable since the middle ages [2]. Ideology of the translator will reflect a good product of translation itself. It is also supported by Bassnett and Lefevere [3] that explain translation is, of course, a rewriting of an original text. All rewritings, whatever their intention, reflect a certain ideology and a poetics and as such manipulate literature to function in a given society in a given way.

Both of them, Basnett and Lefevere, has pointed up that whatever the objective of the translation itself, it will not be inseparable with the ideology of the translator. Ideology of the translator will support in translating any kinds of translation, substantially contain cultural elements, such as; literature translation, newspaper or magazine, movie, humour, science and technology. Each type of text has own difficulties. Nida stated that there are at least four challenges found in translating a text [4]. They are language, socio-cultural, religion, and material culture. However, these three challenges can be categorized into one term, it is culture. Therefore, challenges of the translator consist of two, language and culture. These two things will support the ideology of the translator. Fairclough has stated that language as the primary domain of ideology [5]. It is also backed up by Kress's statement "ideologies find their clearest articulation in language" [6]. Language as a product of culture has convinced that translation might be considered as an ideological activity.

Before translating source text into target text, a translator should know who the target audience and the intention. These two things are the principal process to decide which method will be applied by the translator since it is related to the acceptance or response of the reader to the translation product, good or bad, acceptable or not, etc. Ideology take a role in the procedure of the translation. It plays two roles depend on translator's orientation. There is a translator who focus on source text and another one focus on target text [4]. According to Venuti, translator's ideology can be categorized into two; foreignizing translation and domesticating translation. Both of them are strategies in translation, which correlate with the degree of how the translator follow the target culture [3].

Foreignizing translation is source text-oriented ideology, which retaining information from the source text. In this case, cultural information of the source text are importantly considered for the target reader. The translator is entirely under the control of ST writer. The translator also would like to show and introduce foreign culture that expressed in the language of the reader. For example, the translator will not translate Mr, Mrs, Mom, Dad, etc into Bahasa because these words are already understood and well known by Indonesian. While, domesticating translation is target text-oriented ideology. This ideology stresses on how the translator make the text closely conform to the culture of the language being translated to. Cultural information are obtained from the source text. For this kind of translators, they will translate all words into Bahasa in order to introduce Indonesian culture in all people around the world. Having these kind of ideologies are such propounded, particularly in translating specific terms, such as culture and gender values in literary works.

Indonesian has been common with the English-Indonesian books' translation since easier to understand for Indonesian especially for international best seller books. However, there are not few people also consider that some English-Indonesian translators fail to convey the meaning and it has an effect on readers' response. It may have different point of view if the translation of 
Indonesian-English literatures. There are not many national best seller Indonesian books are translated into other language, like English. One of Indonesian literary works who is appreciated in international level and translated into 30 languages is "Cantik Itu Luka". This novel is written by Indonesian male and has been translated into English by a female translator, Annie Tucker. Annie Tucker has been stayed in Indonesia for years and her understanding of Indonesian cultures are highly appreciated. It has been proven that her translation has driven Eka Kurniawan's creation is recognized as part of international literature [7].

Dewi Ayu as the main character in the novel has shown the gender values trough her characterization. Besides, this novel also describe a history of Indonesian in postcolonialism era. Gender and culture are dominant values shown in this novel. It becomes more fascinating since the writer and the translator of this novel have different gender background that may affect the meaning of SL into TL.

There have been several studies conducted related to translator's ideology in translating cultural terms and gender terms in the product of literature. some of them are; the effect of the translator's gender, ideology on translating Emily Browns' Wuthering Height [8], the impact of translator's ideology on the translation process [9], gender ideology of translator implicated in their translation of Virginia Woolf's novels [10], translation ideology of cultural words used in the translation of Okki Madasari's Kerumunan Terakhir into the last crowd [11] and ideology in translation of cultural lexical items with reference to Perburuan and Fugitive [12]. Among five related studies which carry out the topic about translation, three of them focus on translating from English into other languages, such as Persian or Spain, yet applying different methods, while the rest are focusing on Indonesian into English. There are some results found after analysing, namely how ideology of the translator take a role in interpreting and transforming SL into TL. Furthermore, studies conducted [11], [12] had different results although the source language is same. One has claimed the ideology of the translator tends to domestication [11] and another one tends toward foreignization [12]. These related studies only focus on one point of view and most of it about gender or culture. While, gender and culture are also inseparable since gender ideology is still related to culture system in a nation or country. Therefore, the writer is interested combine culture and gender ideology of the translator in Eka Kurniawan's Cantik itu Luka and its translation in English version [7].

In this paper, the cultural ideology of the translator can be seen by the translation of some cultural terms, which represent Indonesian characterization and its culture. Culture values in this novel do not only focus on terms but also show the way people survive and live their life in post-colonial era while gender issues which are carried out by the writer in this novel sometimes reveal gender discrimination, however, in some parts, women's power is also manifested. According to these issues, problem statements that may be appeared are what the translators' gender and culture ideology which shown through the translator's works.

\section{Method}

This research is descriptive qualitative research. It was conducted using qualitative method. There were approximately 90 data of cultural terms, which show cultural values of ST and TT while data for gender values were manifested in form of events or moments in the story. All terms and descriptions related to cultural and gender values are classified and compared between ST and TT. The data resources in this study consist of two. They were the original version entitled "Cantik Itu Luka" and its translated version, "Beauty is A Wound". There are some steps applied to gather the data; the first was reading both of ST and TT novels. The next steps were highlighting and finding all terms and moments related cultural and gender values to find translator's ideology and understanding the ST. To make it easier, the researcher would 
like to make a column that consist of ST and its translation. the method used in collecting the data is called Simak Bebas Libat Cakap technique (Uninvolved Conversation Observation Technique), which means observing source of data namely Cantik itu Luka as source language and Beauty is a Wound as target language without being involved in a dialogue or conversation to collect the data [13]. After collecting the data, the data were analyzed by using comparative descriptive method. This method is aimed at describing personal character, condition, the symptom or the phenomenon or particular group [14]. Descriptive analysis method is applied only based on reality or language phenomena that exist or live empirically and do not consider the right or wrong the use of the language [15]. This comparative method is used by comparing the similarities and differences one variable or more on two samples or more, or in the different time [16].

\section{Result And Discussion}

\subsection{Culture-Related Terms}

According to Oxford Advanced Learners' Dictionary, Culture is the customs and beliefs, art, way of life and social organization of a particular country or group. In another opinion state most "cultural" words are easy to detect since they are associated with a particular language and cannot be literary translated, but many cultural customs are described in ordinary language [17]..., where literal translation would distort the meaning and a translation may include an appropriate descriptive-functional equivalent. in other words, cultural terms or words cannot be translated literally due to its correlation to particular habit or the way of life of group of people. Newmark has classified culture-related terms in translation into five categories. They are as follows [17]:

1. Ecology: a name for the variety of flora, fauna, plains, and hills.

2. Material culture (artefacts) which classified into four sub-topics such as; food: spaghetti (Italy), Clothes: Kanga (Africa), Kimono (Japan), Kebaya (Indonesia), Houses and towns: joglo (Indonesia), Transport: becak (Indonesia), tuktuk (Thailand).

3. Socio culture - work and leisure.

4. Organizations, customs, activities, procedures, concepts, which divided into three major topics; (a) political and administrative, (b) religious, (c) artistic.

5. Gesture and habits: some gestures and actions that occur in some cultures and not in the others.

According to Oxford Dictionary for Advanced, ecology is the relationship between plants, and living creatures to each other and to their environment. In addition, Newmark has pointed out that ecology includes not only flora, but also fauna [17].

Table 1 Sample data

\begin{tabular}{ll}
\hline \multicolumn{1}{c}{ ST } & \multicolumn{1}{c}{ TT } \\
\hline Membiarkannya porak-poranda dilanda badai & They let its ruins be pummeled by ocean storms, \\
laut, ditumpuki sampah daun kamboja, & $\begin{array}{l}\text { covered by piles of old frangipani leaves, and } \\
\text { grown over with wild elephant grass. }\end{array}$ \\
\hline
\end{tabular}

The sample data above has shown ecology description. The underlined words are still related to the environments. In Indonesia, ST of "rumput gajah liar" is well known with "rumput gajah", which is suited to feed cattle and buffaloes. Besides, it is necessary in the tropic zone due to its high productivity. The term of elephant grass actually refers to some grass species. In Asia, it is known as Mischantus giganteus, used as a biomass crop. In East Africa, it 
is an important forage for elephants and called Napier grass, therefore its name "elephant grass". Even in the Eurasian, this kind of grass is known as Ravenna grass or ekra and called Saccharum ravennae.

The translator prefers translating the term into "wild elephant grass". In this case, it is the literal translation. The translator had better use the term of Napier grass or just "elephant grass".

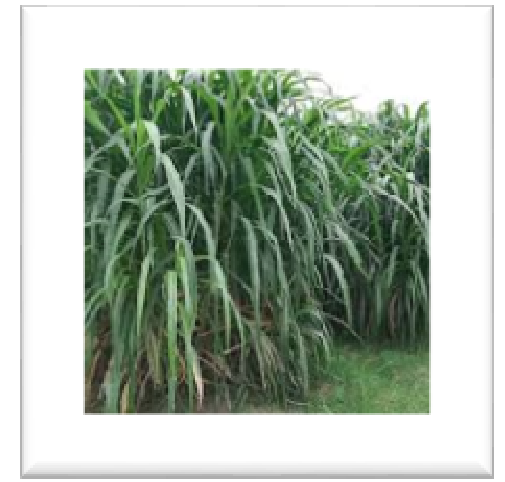

Fig. 1. Elephant grass

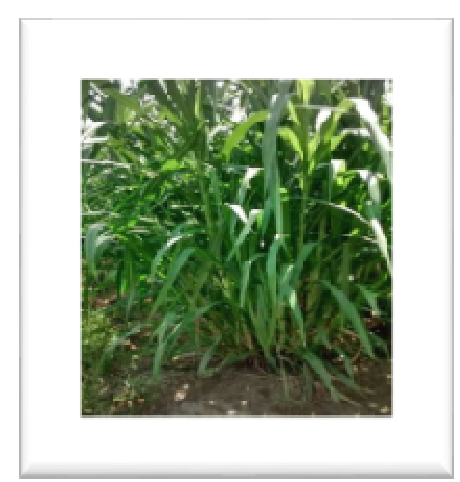

Naphier grass

Table 2 Sample sata

\begin{tabular}{ll}
\hline \multicolumn{3}{c}{ ST (pg. 142) } & \multicolumn{1}{c}{ TT (pg. 137) } \\
\hline Ia lebih banyak menjelajah hutan untuk mencari & He was usually either out exploring the \\
gua-gua dan bermeditasi di sana, jika tidak & jungle looking for caves to meditate in, \\
memancing ikan caroang dan terus melatih fishing for parrotfish, or practicing his & ang \\
kemampuan geraknya dalam pertempuran & combat moves. \\
sungguhan.
\end{tabular}

The case is almost same, in ST, "ikan caroang" is translated into "parrotfish". Whereas, they have different species. Ikan caroang or also well-known as ikan Cendro has a Latin name or common term. It is needlefish while the translator prefers choosing "parrotfish".

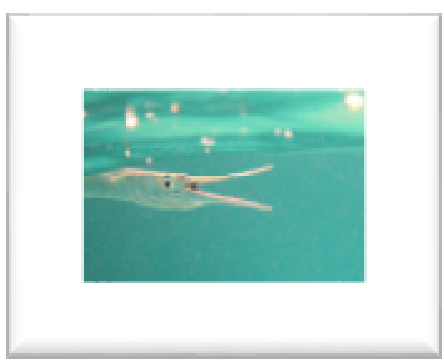

Fig. 2. Needlefish

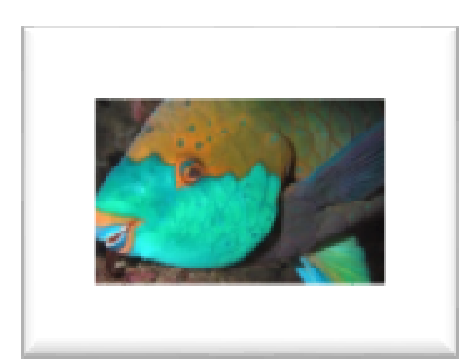

Parrotfish

Material cultures (artefacts) in translation are classified into four sub-topics. They are food, clothes, houses and towns, and transport. In the novel Cantik Itu Luka and its translation, Beauty is Wound, material culture (artefacts) are dominant classification among others. Food is a thing that people or animal eat. Clothes are the things people wear. House or towns are building or place for human live (habitation). Transport is taking or carrying (people or goods) from one place to another by means of vehicle, aircraft, or ship. Here are the data. 
Table 3 Sample Data

\begin{tabular}{ll}
\hline \multicolumn{1}{c}{ ST } & \multicolumn{1}{c}{ TT } \\
\hline $\begin{array}{l}\text { Juga ada penjual bajigur lewat namun tak } \\
\text { mampir... }\end{array}$ & $\begin{array}{l}\text { There was also a bajigur seller who passed } \\
\text { by,.... }\end{array}$ \\
\hline
\end{tabular}

The data shows that bajigur in source text as a kind of traditional drink in Indonesia. According to KBIBI, Bajigur is a drink made of palm sugar mixed with coconut milk. The translator maintains the term of "bajigur" and do not change it into other meaning or explanation. The reason is bajigur is only found in Indonesia, especially in Java. However, there is possibility that the reader cannot understand what bajigur is. In addition, it is such a splash mentioned in the novel. There is no further explanation about it. Bajigur here is included in material culture category since it really shows Indonesia characterization.

Table 4 Sample Data

\begin{tabular}{ll}
\hline \multicolumn{1}{c}{ ST } & \multicolumn{1}{c}{ TT (pg. 85) } \\
\hline $\begin{array}{l}\text {.. dengan sarung ketat serta kebaya dan } \\
\text { rambut disanggul. }\end{array}$ & $\begin{array}{l}\text {.. with a tight sarong and a kebaya blouse and } \\
\text { her hair in a bun. }\end{array}$ \\
\hline
\end{tabular}

Difference from the previous sample data on food, the tern kebaya in target text is translated by giving a clue. That is kebaya blouse. Therefore, the target reader can a bit understand that kebaya is such a formal dress in a formal occasion too.

Other data found that related to material culture are terms of orkes melayu, keroncong, becak, kyai, jihad, sintren, silat, janur kuning, dukun, arisan, etc.

\subsection{Gender Values}

As emphasized on the previous explanation about ideology in translation. Actually, there are still other ideologies applied by the translator in translating the text. One of it is sexism ideology or gender ideology. Lakof [18] has pointed out about ideology on gender discrimination through language. Based on sociolinguistic point of view, there is mind set in a society that women tend to be weak, obedient, and passive [18]. Furthermore, in dictionary is also shown that women are described negatively. In the other hand, men tend to acquire the stereotype of doughty, active, initiative and decision maker and other positive images. This phenomenon is a product of nurture (cultural product).

In Eka Kurniawan's novel, Cantik Itu Luka and its translation, Beauty is A Wound, gender discrimination is close related to gender and women marginalization, gender and subordination, and gender and workload.

1. Gender and women marginalization

Some problems occurred in a society such as eviction, exploitation, and natural disaster can cause a marginalization and it is one of source of poverty in a society or even in a country.

Para pejabat Jepang itu kemudian datang, memeriksa mereka satu persatu. Mereka berdiri di depan perempuan-perempuan itu, tertawa kecil sambil memperhatikan tubuh si gadis, dari ujung rambut sampai ujung kaki. Kadang-kadang mereka harus mengangkat wajah beberapa orang gadis dengan menekan dagunya dengan ujung jari. Mereka nyengir dan kembali memeriksa perempuan-perempuan yang lain. Beberapa orang gadis nyaris tak sadarkan diri oleh terror semacam itu [7].

Then the officers came, examining them one by one. They stood in front of each women, laughing quietly while scrutinizing her body, from the top of her head down to the tips of her toes. Sometimes, to get a better look at her face, they'd lift up her chin with their fingertips.

The description above show that Japanese soldiers treat women arbitrarily. Unfortunately, the momen described by the translator is not too dramatic as ST. 
2. Gender and subordination

Gender perspective could create subordination toward women. Subordination may be occurred since gender problems or issues can develop in the any different forms from one place to another place, from time by time.

Dewi Ayu thought she should marry Maya Dewi off as quickly as possible, before she grew up and went wild. For years she had always solved her problems with quick thinking, and the first idea that popped into her head was always the very thing that she did next. She didn't want to see Maya Dewi grow up to face the same tragic fate that had befallen Allamanda and might yet befall Adinda.

By seeing the quote above, Maya Dewi is facing gender discrimination because she is forced to get marry in her young age, 12 years old. Her mother does not want to let her play with her friends. It seems unfair for Maya Dewi because Dewi Ayu consider that Maya Dewi will become as what happened to her sisters while it is just her anxiety.

3. Gender and Workload

"Mama, loan me some money. I want to buy my house back". Mama Kalong looked at everything from a financial angle and could always spot a good business opportunity. "And how will you repay me?"

"I have a family treasure," replied Dewi Ayu. "before the war I buried all of my grandmother's jewelry in a secret place and no one knows about it except me and God."

"And what if God stole it?"

"Then I'll come back and whore for you to pay off my debt".

It seems women can do everything not only for domestic things, but also for being responsible to herself, family and others. It is reflected by Dewi Ayu that she does not only become a mother of 3 daughters but also become a breadwinner.

The translator has applied some ideologies in translating ST into TT. Foreignization ideology of the translator is dominant in translating cultural-related terms. The translator keeps maintaining all terms, which really characterize Indonesian. The good thing of it is the target reader also can understand some Indonesian culture although some words are not described in detail. Domestication ideology of the translator has shown dominantly in translating some terms related to ecology although there might be misunderstanding in translating some terms.

Ideology of gender equality has influenced the translator in the process of translation. It is proven by the translator's work which reflect her understanding and schemata of a culture perspective in a society. However, some sample data cause distortion because the translator loses some dramatic moments in the story.

\section{Conclusion}

Foreignization and domestication are strategies used by the translator in translating ST into TT. However, it relies on the translator's schemata and finally affect the translator's ideology. Besides foreignization and domestication, there is also sexism ideology which refer to gender issues translation. Overall, the translator of Cantik itu Luka into Beauty is Wound has been successfully transfer the meaning although there are still misperception of some terms which may be related to cultural terms, while in gender perspective, the writer describe the story more dramatic and impressive than the translator. 


\section{Acknowledgements}

The authors would like to thank for my supervisors and my translation lecturer, Prof. L.M. Manda for supervising me.

\section{Reference}

[1] S. Hamerlain, "Translation as Transmitter of feminist Ideology," Ann. du Patrim. No. 03/2005, p. $55-58,2005$.

[2] P. Fawcett, Ideology and Translation in Baker, M. (ed). Routledge Encyclopedia of Translation Studies. London: Routledge.

[3] L. Venuti, The Translator's Invisibility: A History of Translation. London and New York: Routledge, 1995.

[4] B. H. Hoed, Penerjemahan dan Kebudayaan. Jakarta: Pustaka Jaya, 2006.

[5] N. Fairclough, Language and Power. London: Longman, 1989.

[6] G. R. Kress, Linguistic Precesses in Sociocultural Practice. Victoria: Deakin University Press, 1985.

[7] E. Kurniawan, Cantik itu Luka. Jakarta: Gramedia Pustaka Utama, 2004.

[8] S. G. Shafiee-Sabet and A. Rabeie, "The Effect of the Translator's Gender Ideology on Translating Emily Bronte's Wuthering Heights,” J. Lang. Teach. Ski., vol. 3, no. 3, pp. 144-158, 2011.

[9] A. M. R. López and M. R. Caro, "The Impact Of Translators' Ideology On The Translation Process: A Reaction Time Experiment," MonTI. Monogr. Traducción e Interpret., no. Special Issue, pp. 248-271, 2014.

[10] A. Boostani, "Gender Ideology of Translator Implicated in Their Translation of Virginia Woolf's Novel," Sci. J., vol. 36, no. 3, pp. 1300-1949, 2015

[11] N. R. Latifah, "Translation Ideology of Cultural Words Used in the Translation of Okki Madasari's Kerumunan Terakhir into The last Crowd," Faculty of Adab and Cultural Sciences. State Islamic University Sunan Kalijaga, 2018.

[12] C. M. D. Utami, I. A. M. Puspani, and N. W. Sukarini, "Ideology In Translation Of Cultural Lexical Items With Reference To Perburuan And Fugitive," Semant. Sch., vol. 4, no. 1, pp. 6069,2018

[13] Sudaryanto, Metode Linguistik: Metode dan Aneka Teknik Pengumpulan Data. Yogyakarta: Gajah Mada University Press, 1988.

[14] Koentjaraningrat, Metode-Metode Penelitian Masyarakat. Jakarta: Gramedia Pustaka Utama, 1985.

[15] Sudaryanto, Metode Linguistik: Bagian Pertama ke Arah Memahami Metode Linguistik. Yogyakarta: Gadjah Mada University Press, 1986.

[16] Sugiyono, Metode Penelitian Pendidikan Pendekatan Kuantitatif Kualitatif dan R\&D. Bandung: Alfabeta, 2009

[17] P. Newmark, A Textbook of Translation. New York: Prentice Hall, 1998.

[18] R. Lakof, Language and Women's Place. New York: Harper \& Row, 1975. 